\title{
The Role of Foreign CRedentials And ETHNic Ties In IMMigRANTS’ ECONOMIC PERFORMANCE ${ }^{1}$
}

Peter S. Li

\begin{abstract}
The literature has identified foreign credential devaluations and the shifting origins of immigrants to non-European sources as two factors that explain why some immigrants earn more than others. This study uses data from the Ethnic Diversity Survey to see how foreign credentials affect immigrants' earnings, and whether immigrants with disadvantaged foreign credentials may be able to use ethnic social capital to mitigate the negative effect. Substantial gross earnings disparities exist among immigrant men and women of different origins, but much difference is due to human capital variations and duration of work. The study produces three major findings. First, foreign credentials benefit majority member immigrants but penalize visible minority immigrants. Second, immigrant men and women who maintain weak ethnic ties earn more than their counterparts with strong ties, suggesting that the enabling capacity of social capital for immigrants has been overstated. Third, there is no evidence of ethnic social capital being able to mitigate the negative effect of a credential deficit.
\end{abstract}

Résumé. La documentation du domaine a identifié deux facteurs qui expliquent pourquoi certains immigrants gagnent plus d'argent que d'autres: la dévaluation des titres de compétences étrangers et l'évolution de l'origine des immigrants vers des sources non-européennes. Cette étude puise dans des données de l'Enquête sur la diversité ethnique pour comprendre l'effet des titres de compétences étrangers sur le revenu des immigrants d'une part, et pour déterminer si les immigrants avec des titres de compétences étrangers défavorisés peuvent recourir au capital social ethnique pour atténuer cet effet négatif, d'autre part. Il existe

1. Research for this paper was supported by grants provided by Social Sciences and Humanities Research Council and the Prairie Centre of Excellence for Research on Immigration and Integration. The permission by Statistics Canada to use the Research Data Centre at the University of British Columbia is gratefully acknowledged. The author would like to thank Lee Grenon for his helpful advice and technical support in accessing data at the Research Data Centre. The author is solely responsible for the use and interpretation of the data. The author also benefits from the helpful comments of the anonymous reviewers. 
des disparités significatives sur le plan du salaire brut parmi les immigrants et les immigrantes de différentes origines, mais une grande partie des différences sont attribuables aux écarts dans le capital humain et la durée de l'emploi. Trois conclusions importantes se dégagent de l'étude. D'abord, les titres de compétences étrangers représentent un bienfait pour les immigrants membres d'une majorité, mais un désavantage pour les immigrants membres d'une minorité visible. Deuxièmement, les immigrants et les immigrantes dont les liens ethniques sont faibles gagnent un revenu qui est supérieur à celui de leurs homologues qui entretiennent des liens ethniques serrés, ce qui semblerait indiquer que l'appui que fournit le capital social aux immigrants a été surévalué. Troisièmement, rien n'indique que le capital social ethnique pourrait atténuer l'effet négatif d'un déficit sur le plan des titres de compétences.

esearch on immigrants' earnings focuses on the concept of human capital to explain why some immigrants do better than others. Immigrants' foreign credentials and experiences are typically not well recognized in Canada (deSilva 1997; Li 2001a; Reitz 2001a; 2001b); data limitations have restricted analysis of how this affects immigrants and how immigrants with less-valued human capital compensate for the deficiency. This paper uses data from the Ethnic Diversity Survey to show how foreign credentials and Canadian credentials affect immigrants' earnings, and how immigrants with less-valued credentials may be able to use social capital to compensate for the credential deficit.

\section{Human Capital and Social Capital}

The literature on the economic performance of immigrants makes two key observations related to immigrants' human capital. The first relates to the devaluation of immigrants' foreign credentials in the Canadian labour market; the magnitude of devaluation depends on many factors, including gender, race, country of origin, age at immigration, and other features (deSilva 1997; Li 2001a; Reitz 2001a; 2001b; Schaafsma and Sweetman 2001). Less than full recognition of immigrants' foreign credentials results in substantial income loss for some immigrants, especially for groups already disadvantaged by gender and racial features (Li 2001a; Reitz 2001a; Aydemir and Skuterud 2005). The problem of immigrants' foreign credentials is further compounded by the rising education levels of native-born Canadians (Reitz 1998; 2001b). More recent immigrants, mainly from Asia, Africa, and the Caribbean, face an increasingly competitive labour market in Canada - a phenomenon that is also encountered by native-born new entrants to the labour market (Green and Worswick 2002). 
The devaluation of immigrants' human capital relates to foreign work experience, in addition to credentials. Several studies suggest that immigrants' foreign work experience, especially from countries outside of Europe and North America, yields little or no return in Canada, in contrast to the positive return of Canadian experience (Green and Worswick 2002; Schaafsma and Sweetman 2001).

The second observation of immigrants' human capital concerns recent immigrants from non-European continents, mainly Asia and Africa. The compositional shift implies that more recent immigrants to Canada have different language features, foreign credentials, and experiences than earlier immigrants of primarily European origin (Aydemir and Skuterud 2005; Green and Worswick 2002; Schaafsma and Sweetman 2001; Worswick 2004). This point is usually made to explain why immigrants to Canada in the 1980s and 1990s earned less than immigrants who arrived in earlier decades (Abbott and Beach 1993; Bloom and Gunderson 1991; Bloom, Grenier, and Gunderson 1995; Coulson and DeVoretz 1993), and why the deterioration of immigrants' earnings in succeeding arrival cohorts has continued despite the higher educational level of more recent cohorts (Aydemir and Skuterud 2005; Frenette and Morissette 2003; Schaafsma and Sweetman 2001; Reitz 1998; 2001a; Worswick 2004; Wanner 2003). Aydemir and Skuterud (2005) attribute roughly one-third of the earnings decline of successive immigrant cohorts between 1981 and 2001 to the compositional shift. This implies that the credentials of earlier immigrant cohorts were more likely from Europe and the US and those of more recent cohorts were more likely from Asia, Africa, and non-European countries. A larger composition of immigrants from non-European source countries will likely result in a larger pool of immigrants whose credentials and human capital contents are less valued in Canada. This partially explains why recent immigrants, even with higher education, earn less than earlier arrivals.

Both of these key observations suggest substantial discounting of immigrants' non-Canadian credentials, and non-European source credentials are discounted even more. Thus, immigrants with undervalued foreign credentials carry a human capital deficit. However, not much is known about how these immigrants compensate for their credential deficiency to maximize their economic gains.

The literature suggests another form of capital - social capital that may explain how some immigrants mobilize social relations to overcome hardships and insufficiencies. The renaissance of research on social capital has rekindled interest in how an individual's connections to a social group can provide group-based resources to enable individual economic gains (Bourdieu 1986; Coleman 1988; Granovetter 1985; 
1995). Researchers stress different components of social capital, such as trust (Putnam 1993:167-176), social network or ties (Granovetter 1985; Lin, Cook, and Burt 2001), group solidarity and reciprocity (Portes and Sensenbrenner 1993). Despite the different emphases, there is general agreement that social capital represents an enabling capacity or resource possessed by any individual attached to a social group (Li 2004). Social capital can be measured by a person's connection to social groups (social ties), or the extent to which an individual is a member of a social group (Granovetter 1985; Lin, Cook, and Burt 2001).

The usefulness of attachment to one's ethnic group is well noted in the literature. However, there are conflicting claims on whether ethnic ties impede or enhance individuals' economic opportunity. Reitz and Sklar (1997:234) summarized the literature of assimilation in what they called "the classic hypothesis" - the maintenance of ethnic identity, social networks, and institutional affiliations come with heavy costs to ethnic members in lost opportunities in good jobs and earnings. Since assimilation is compelling in both the United States and Canada (Reitz and Breton 1994), ethnic groups and minority members who are slow to assimilate tend to be penalized in earnings and economic status. A strong maintenance of ethnic ties or attachments indicates a weak assimilation to mainstream society. The Canadian literature confirms an earnings penalty for those who are more ethnically connected (Kalbach and Kalbach 1995; Pendakur and Pendakur 2002; Li 2001b). These observations echo the ethnic mobility entrapment thesis first advanced by Wiley (1967), who explained the limitation of minority members relying too much on ethnic ties and ethnic sponsorship. The limitation is an opportunity cost, that is, the missed opportunities in larger society for ethnic members who become too firmly embedded in a network of ethnic relations that provide them with economic opportunities in the ethnic community (Wiley 1967:151).

Since the late 1970s, there has been a growing interest in the immigrant enclave economy based on social relations and ethnic solidarity (Wilson and Martin 1982; Wilson and Portes 1980). The ethnic enclave economy thesis, originally proposed by Wilson and Portes (1980), postulates that an immigrant-based economy thrives as a separate, protected, and unified system. Common language and ethnic affinity benefit immigrant businesses; immigrant workers enjoy positive returns on past human capital investment similar to the primary labour market. Even before the development of the ethnic enclave economy thesis, there was a strong interest to understand why, despite market disadvantages, some ethnic and racial minorities are more successful economically than others (Light and Gold 2000:206-212). Many studies conclude that 
when opportunities are limited, groups endowed with ethnic resources of values, networks, and social organizations stand a better chance of overcoming obstacles and developing strategies for economic advancement (Bonacich and Modell 1980; Cummings 1980; Light 1972; Light and Bonacich 1988; Light and Rosenstein 1995; Waldinger et al. 1990; Ward and Jenkins 1984). The notion of an enclave encompasses many dimensions, including social ties, ethnic solidarity, cultural values, and social organizations. It is clear from the enclave literature that ethnic ties and affiliations can be instrumental to immigrants in overcoming blocked mobility in the open market by allowing them to use ethnic ties to consolidate a sheltered economy.

The literature provides a mixed assessment of how ethnic attachments affect immigrants' economic opportunities, but the understanding of ethnic attachments is not the same. It varies from social connections or ties with ethnic members to group solidarity based on common language, origin, and culture. Despite the difference in emphasis, the common theme underlying the assimilation perspective and the enclave thesis suggests that the way a minority member is connected to the minority community affects economic outcomes. In particular, ethnic connections are seen as a compensation for market disadvantages. Ethnic attachments or ties therefore constitute a form of social capital measured by the extent to which an individual is attached to one's ethnic group.

Despite the compelling findings reported in the literature on human capital (immigrants' foreign credentials) and the growing interest in social capital (ethnic or social connections), there has been little integration of the two forms of capital to understand how they affect immigrants' economic performance. It appears that social ties or connections, as a form of social capital, enable some immigrants to advance their economic interests, overcoming human capital deficiencies. Previous studies on immigrants' foreign credentials used census data that do not provide information on the country or continent from which the credentials were obtained, or data on social ties of immigrants. Thus, immigrants' foreign credentials can only be crudely estimated based on the age of immigration (deSilva 1997; Li 2001a), and analyses on immigrants' social capital cannot be performed using census data.

The Ethnic Diversity Survey provides data on where immigrants obtained their credentials as well as information on ethnic ties or connections. In the following analysis, direct measurements of foreign credentials of immigrants are used to analyze how foreign credentials affect immigrants' earnings, and data on ethnic ties are used to measure ethnic social capital to see if they improve the earnings opportunities of immi- 
grants, especially for those who may be seen as having a human capital deficit.

\section{Data And Method}

The analysis is based on data from the Ethnic Diversity Survey, a post 2001 Census survey jointly sponsored by the Department of Canadian Heritage and Statistics Canada. The survey was conducted by telephone interview, about 35 to 45 minutes each, between April and August 2002. Respondents were selected from those who completed the long questionnaire form (2B) of the 2001 Census. The target population was persons 15 years of age and older living in private dwellings in the ten provinces. Those on Indian reserves, persons who declared an Aboriginal origin in the 2001 Census, and those in territories and remote areas were not included. The target population has 42,476 unweighted cases representing $23,092,643$ weighted persons (Statistics Canada 2002). The survey was based on a probabilistic sample which involves a complex multistage and multistrata sampling design. The response rate for the entire sample is 75.6 percent, but response rate by stratum varies between 72 to 80 percent (Statistics Canada 2002:6).

The analytical file of the Ethnic Diversity Survey was released to researchers in Statistics Canada's research data centres. To properly weigh the sample respondents to arrive at population estimates, Statistics Canada provides a sample weight to be used for point estimation, and 500 replicate weights or "bootstrap weights" to be used for estimating sample variance needed for tests of significance. ${ }^{2}$ For confidentiality protection, Statistics Canada stipulates that only results based on weighted data, that is, data weighted by the sample weight, may be released to researchers. In this analysis, both the sample weight and bootstrap weights have been applied in the analysis. ${ }^{3}$

Among the respondents in the survey were 5.2 percent who either did not complete the survey on their own or were eliminated in the interview process because they indicated an Aboriginal origin. These cases were

2. According to Statistics Canada, the 500 bootstrap weights were produced in 500 samples selected, using certain independent variables from the original sample. Initial weights were first calculated for each sample, and then with replacements, adjustments to the weights were made taking into account nonresponse, a posteriori stratification, and making use of ranking ratio estimation method (Statistics Canada 2002).

3. The software WESVAR 4.2, available at Statistics Canada's research data centres, was used to process the bootstrap weights for variance estimation used in tests of significance in the models. 
excluded from the analysis to concentrate on the effect of immigrants' credentials, including foreign and Canadian credentials, on earnings, and the ability of some immigrants to overcome a credential deficit by using ethnic social ties as social capital. Since the analysis is on the effect of human and ethnic social capital on employment earnings, unpaid family workers and those who did not provide answers as to whether they worked or not were also excluded from the analysis. Of the rest, only those between 25 and 64 years of age were included, avoiding the retired population and the possible school-attending population. The sample used in the analysis has 2,571,461 weighted cases, of which 53 percent were men and 47 percent women.

The Ethnic Diversity Survey provides data on ethnic origin; the level, type, and origin of educational credentials; total income; ethnic ties relating to the ethnic origin of coworkers, friends, members of voluntary associations; and other information. Selected data from the 2001 Census pertaining to years of schooling, job, and income were linked to the data file of the Ethnic Diversity Survey. The income data in the Ethnic Diversity Survey were based on one single question that asked about the total earnings in the past 12 months. The census income data, based on 2000 calendar year earnings, were obtained from several questions, and the detailed income data allow employment earnings to be separated from the total income.

The analysis uses actual earnings - wages, salaries, and self-employed income, as reported for 2000 in the 2001 census - as the dependent variable. Portes and Zhou (1996) compared the use of logged and raw earnings of immigrants in the literature. They concluded that the use of logged earnings results in a better fit by normalizing outliers, making it more suitable for studying average rates of return. The use of raw earnings more truly reflects the influence of outliers and is a better choice for studying absolute economic outcomes. A handful of cases had negative employment income and they were not included in the analysis.

Separate regressions are estimated for immigrant men and immigrant women. Seven racial and ethnic origins are used in the analysis, and they are coded as dummy variables using the British as the reference group. The origins include: four visible minority groups made up of Chinese; South Asian; Black; and other visible minorities, and three majority groups made up of British; North and West Europe; and other majority members. These groups are based on detailed information on visible minority status and on the first response of ethnic ancestry from the Ethnic Diversity Survey.

Two other types of independent variables are used in the models. The first pertains to human capital and work-related features, including 
the years of schooling, whether the highest university credential was obtained in Canada or specific regions outside of Canada, years of foreign work experience, the years in Canada since immigration to Canada, ${ }^{4}$ whether the respondent speaks an official language as their first language, the number of weeks worked in 2000 , whether one works in a metropolitan centre, and whether the weeks worked were mainly full time or part time.

The second type includes three measurements of ethnic social capital, using ethnic ties among coworkers, friends, and members of the first social organization to which the respondent belonged. For each type, respondents were asked to indicate whether all, most, or some of the coworkers, friends, or fellow members were of the same ethnic origin as the respondent. The more similar the ethnic origin of coworkers, friends, and fellow members is to the origin of the respondent, the more the respondent is attached or connected to ethnic social capital. The more ethnic connections a person has, the more ethnic social capital may be mobilized.

Using ordinary least squares solutions, the analysis first compares the differences in gross earnings among immigrants of seven racial and ethnic origins. Net earnings differences are then estimated after variations in schooling, foreign credentials, foreign work experience, years in Canada since immigration, official language proficiency, and workrelated features including the location and duration of work in 2000 are taken into account. Net earnings differences are calculated after further adjusting for the foregoing variables as well as variations in the three measurements of ethnic social capital. In the final model, interaction terms of visible minority foreign credentials and different levels of ethnic social capital are included to see if different levels of ethnic social

4. The literature on immigrants' earnings stresses the variable "years since immigration," whereas the literature on human capital uses the variable estimate "years of work experience." The variable "years of work experience" is typically estimated by: age-schooling-5 (equation 1), and the variable "years since immigration" is measured by: age-age at immigration (equation 2). Immigrants' years of work experience can be further decomposed into two parts: years of foreign experience and years of Canadian experience. The variable "years of foreign work experience" may be estimated by: age at immigrationschooling-5 (equation 3). If the value of years of foreign work experience is less than one, it implies the completion of schooling after immigration and therefore no foreign work experience prior to immigration; the value should be set to zero. The variable "years of Canadian work experience" can then be estimated by: years of work experience-years of foreign work experience, or equation 1 minus equation 3 . It can be seen that for adult immigrants, the variable "years of Canadian work experience" and "years since immigration" are identical. For consistency with the literature on immigration research, the variable "years since immigration" is used in this analysis. 
capital enables those with disadvantaged foreign credentials to mitigate the negative effects of credential deficiencies.

\section{FindingS}

Gross earnings differences among men indicate that visible minority immigrants earn substantially less than immigrants of British origin (Model 1 , Table 1), varying from over $\$ 18,000$ a year less for immigrants of Chinese and Black origin to $\$ 13,000$ less for immigrants of South Asian origin and other visible minority origin. Compared to immigrant men of British origin, immigrant men of other majority origin also earn less, but they do better than Asian male immigrants. For example, male immigrants from North and West Europe earn \$3,249 less than immigrant men of British origin, and immigrant men from other majority origin earn about $\$ 8,000$ less. Thus, there are substantial gross earnings differences among immigrant men of different racial and ethnic origins.

Controlling human capital differences and duration and location of work (model 2) substantially reduces the earnings disparities among immigrant men of different origins, suggesting that much of the original difference is due to variations in the variables now being controlled. Visible minority immigrant men still earn less than majority member immigrants. For example, Chinese and Black male immigrants now earn $\$ 5,872$ a year less than British immigrant men. Those from North and West Europe only earn marginally less than British immigrant men, and those from other majority member origin earn $\$ 1,731$ less a year. These earnings differences are no longer statistically significant.

Those who worked full time and more weeks earned more than their counterparts who worked part time and fewer weeks respectively. Those who worked full time earned $\$ 20,000$ a year more than part-time workers; each additional week worked increased annual earnings by over $\$ 800$. Those who lived in census metropolitan areas did not have a statistically significant earnings advantage over immigrants in nonmetropolitan areas when other variables were controlled. Most of the human capital variables had a positive effect on earnings, except foreign work experience and official languages fluency. ${ }^{5}$ Each additional year of schooling

5. The Ethnic Diversity Survey does not have a variable that measures the proficiency in official languages. The question available in the survey that seems to be able to distinguish those who speak official languages fluently and others not so fluently is the one on whether the respondent learned an official language as a first language. But this variable does not indicate properly those who may have learned the official languages well but not as the first language. 
Table 1: Effect of Human Capital and Ethnic Social Capital on Employment Earnings for Majority and Minority Male Immigrants

\author{
Number \\ Model

$[1] \quad[2] \quad[3]$ \\ [4]
}

Independent Variables
Ethnic origin (reference group: majority member
British)

British)

Visible minority: Chinese

$\begin{array}{lllll}166,376 & -18,792 * & -4,863 & -5,383 & -5,754\end{array}$

Visible minority: South Asian

$\begin{array}{lllll}169,692 & -12,934 * & 144 & -1,966 & -2,144\end{array}$

Visible minority: Black

$\begin{array}{lllll}48,409 & -18,838^{*} & -5,872 & -9,549 * & -9,975^{*}\end{array}$

Visible minority: Other

$\begin{array}{lllll}176,090 & -13,534^{*} & -2,879 & -3,983 & -4,169\end{array}$

Majority member: North and West Europe

$\begin{array}{lllll}129,653 & -3,249 & -753 & -1,819 & -1,894\end{array}$

Majority member: Other

324,875

$-4,694$

Majority member: British

137,884

No. of weeks worked in 2000

$848 * \quad 859 * \quad 854 *$

Worked full time

$20,467 * 20,142 * 19,953^{*}$

CMA

Total years of schooling

Foreign credentials

$4,945 \quad 4,284 \quad 4,519$

$2,712 * \quad 2,557 * \quad 2,560 *$

Foreign credentials x visible minority

$6,803 * \quad 6,809 * \quad 7,033 *$

Speak official language

$-8,105^{*}-8,484^{*} \quad-9,978$

Years of foreign work experience

$450 \quad 445 \quad 784$

Years in Canada

$50 \quad 64 \quad 54$

$509 * \quad 453 * \quad 453 *$

Friends with same ethnic ancestry (reference group: few or none)

All/most friends with same ethnic ancestry $\quad-2,963 \quad-3,358$

$\begin{array}{lll}\text { Half friends with same ethnic ancestry } & 1,290 \quad 372\end{array}$

Coworkers with same ethnic ancestry (reference groups: few or none)

All/most coworkers with same ethnic ancestry

$-6,022 *-8,150 *$

Half coworkers with same ethnic ancestry

$-4,720 *-5,988 *$

Belong to organizations with members same ethnic ancestry (reference group: not belong to any organization)

All/most members in organization same ethnic ancestry

$11,370 * 15,937 *$

Half members in organization same ethnic ancestry

$-6,708-9,688^{*}$

Few/none in organization same ethnic ancestry/

ethnicity unimportant

$2,880 \quad 2,405$

Foreign credentials, visible minority status

$\mathrm{x}$ all/most friends with same ethnic ancestry

$x$ half friends with same ethnic ancestry

$x$ all/most coworkers with same ethnic ancestry

$x$ half workers with same ethnic ancestry

$\mathrm{x}$ all/most members in organization same ethnic

$\mathrm{x}$ half members in organization same ethnic

ancestry

Intercept

$0.022 * 0.205 * 0.220 *$

$0.224 *$

Note: $* \mathrm{p} \leq 0.05$

Source: Ethnic Diversity Survey, Analytical File, Research Data Centre. Sample weights were applied to obtain point estimates, and bootstrap weights provided by Statistics Canada were used to estimate variance. 
increased annual earnings by $\$ 2,712$. Foreign credentials also had a positive effect, netting $\$ 6,803$ a year. However, the advantage became a penalty of $\$ 1,302$ a year for visible minority men with foreign credentials. In other words, compared to immigrants with Canadian credentials, the foreign credentials of immigrant men of majority member background were an advantage in earnings, but those of immigrant men of visible minority background were a disadvantage. These findings suggest that some of the income disparities between majority member male immigrants and visible minority male immigrants can be attributed to the difference in market value of foreign credentials held by these two groups. Each year of experience in Canada brought an earnings advantage of about $\$ 500$, but foreign work experience did not result in an improvement in earnings. This finding confirms that foreign work experience is largely not recognized in Canada.

The effect of ethnic social capital is considered in model 3 along with human capital and other variables. British male immigrants continue to have the highest earnings, and Black male immigrants, the lowest $(-\$ 9,549)$. The rank order of earnings of other groups remains the same, although the differences are not statistically significant, except for Black immigrant men.

Foreign credentials held by majority male immigrants continue to bring an earnings advantage of $\$ 6,809$ a year, but those of visible minority men produce a net disadvantage of $\$ 1,675$ a year. The effects of years of schooling and years in Canada are only slightly reduced when other variables are controlled.

The net effect of ethnic social capital on earnings varied, depending on whether the measurement used is ethnic friends, coworkers, or ethnic social organization. Association with different levels of friends of the same ethnic origin had no significant effects on earnings of men. Immigrant men reporting all or most coworkers belonging to the same ethnic ancestry suffered the worst penalty in earnings $(-\$ 6,022)$, followed by those reporting half of the coworkers of the same ancestry $(-\$ 4,720)$, compared to those who had few or no coworkers of the same ancestry. Immigrants who cluster in a workplace predominated by immigrants of the same origin probably work in an immigrant enclave setting. As Wiley's (1967) ethnic mobility trap thesis suggests, ethnic social capital may be useful in helping an immigrant to find a job in the ethnic enclave, but the immigrant suffers in not being able to maximize opportunities outside of the enclave. A recent study of the immigrants in the enclave and mainstream economy in Canada also indicates that those who work in the immigrant enclave earn less than those who participate in the mainstream economy ( $\mathrm{Li}$ and Dong 2007). The negative effect of having 
too many coworkers belonging to the same ethnic ancestry on earnings probably reflects the disadvantage associated with working in an enclave even though the ethnic connection may have been instrumental in landing the immigrant with the enclave job in the first place.

Immigrant men belonging to a social organization in which all or most members belong to the same ethnic ancestry had a net earnings advantage of $\$ 11,370$ a year, compared to those who did not belong to any organization. This finding suggests that compared to immigrants not connected to any social organization, there is a positive effect on earnings for immigrant men to be associated with a social organization with members of predominantly the same ethnic ancestry.

In model 4 , interaction terms of foreign credentials held by visible minority men and various levels of ethnic social capital are added. The purpose is to see if ethnic social capital enables those immigrants with a credential deficit to mitigate some of the negative effects of foreign credentials. The results indicate that most of the interaction terms do not produce a statistically significant effect on earnings. The exception is the interaction between visible minority foreign credentials and belonging to a social organization in which all or most members belong to the same ancestry. This interaction term produces a significant negative effect of $-\$ 12,427$ a year, net of other variables. In other words, for visible minority men with foreign credentials, the net gain of belonging to an ethnic social organization is reduced from $\$ 15,937$ to only $\$ 3,510$ a year. The finding indicates that there is no evidence of ethnic social capital being able to mitigate the negative effect of credential deficit held by visible minority men.

Black male immigrants continue to earn the least, $\$ 9,975$ a year less than British male immigrants, and the difference is statistically significant. Much of the original difference in earnings among immigrant men of various racial and ethnic background is not statistically significant after controlling for variations in human capital, social capital, and other features, suggesting that much of the earnings differences among racial and ethnic groups is accounted for by the variables controlled.

The results for immigrant women are reported in Table 2. The gross earnings (Table 2, model 1) indicate that visible minority female immigrants earn between $\$ 5,620$ and $\$ 7,249$ a year less than British immigrant women and generally less than majority member immigrants, but the disparities are not as large as those found among men.

When variations in human capital and other work-related features are controlled, only Black female immigrants earn less than British female immigrants. (Table 2, model 2). However, the earnings differences are not statistically significant. The original earnings differences among 
Table 2: Effect of Human Capital and Ethnic Social Capital on Employment Earnings for Majority and Minority Female Immigrants

\section{Independent Variables}

Ethnic origin (reference group: majority mem-

ber British)

Visible minority, Chinese

Visible minority, South Asian

Visible minority, Black

Visible minority: Other

Majority member: North and West Europe

Majority member: Other

Majority member: British

No. of weeks worked in 2000

Worked full time

CMA

Total years of schooling

Foreign credentials

Foreign credentials $\mathrm{x}$ visible minority

Speak official language

Years of foreign work experience

Years in Canada

Friends with same ethnic ancestry (reference group: few or none)

All/most friends with same ethnic ancestry

Half friends with same ethnic ancestry

Coworkers with same ethnic ancestry (reference groups: few or none)

All/most coworkers with same ethnic ancestry

$\begin{array}{rlrrr}141,715 & -5,732 * & 3,529 & 4,041 & 4,159 \\ 129,579 & -5,620 * & 2,873 & 1,930 & 2,334 \\ 62,482 & -6,198 * & -3,536 & -3,099 & -2,787 \\ 190,184 & -7,249 * & 2,105 & -549 & -205 \\ 90,034 & -5,127 * & -385 & -3,853 & -3,861 \\ 270,941 & -2,855 & 3,186 & 999 & 1,194\end{array}$

127,284

$449 * \quad 435 * 432 *$

$14,861 * 14,571 * 14,623 *$

$2,849 \quad 2,561 \quad 2,501$

$2,217 * \quad 1,991 * 1,988^{*}$

$1,783 \quad 3,770 * 3,956^{*}$

$-3,030 \quad-4,183 \quad-5,192$

$4,891 \quad 1,508 \quad 1,468$

$329 \quad 105 \quad 109$

$431 * 412 * 414 *$

$-3,110^{*}-4,249 *$

$-2,345 \quad-2,218$

$-1,975-4,249 *$

$2,737-2,218$

Half coworkers with same ethnic ancestry

Belong to organizations with members same ethnic ancestry (reference group: not belong to any organization)

All/most members in organization same ethnic ancestry

$1,447 \quad 2,415$

Half members in organization same ethnic ancestry

Few/none in organization same ethnic ancestry/ ethnicity unimportant

$4,424 * 4650 *$

Foreign credentials, visible minority status

$\mathrm{x}$ all/most friends with same ethnic ancestry

$\mathrm{x}$ half friends with same ethnic ancestry

$x$ all/most coworkers with same ethnic ancestry

$x$ half workers with same ethnic ancestry

$\mathrm{x}$ all/most members in organization same eth-

ic ancestry

ancestry

$\mathrm{x}$ few/none in organization/ethnicity unimportant

Intercept

$33,365^{*}-52,235^{*}-43,980 *-43,986^{*}$

R Square 
female immigrants of various racial and ethnic backgrounds can be attributed to variations in human capital and duration of work.

Those who worked full time netted an additional $\$ 14,861$ a year compared to immigrants who worked part time; each additional week worked brought an annual increase of $\$ 449$. Similar to immigrant men, human capital increases the net earnings for immigrant women. Each additional year of schooling increases employment earnings by $\$ 2,217$ a year and each additional year in Canada raises the yearly earnings by $\$ 431$, when the duration of work and other variables are controlled. As before, foreign credentials have a positive effect of increasing the annual earnings by $\$ 1,783$ a year for female majority members, but decreasing the annual earnings by $\$ 1,247$ for female visible minority immigrants. However, the effects are not statistically significant. Again similar to immigrant men, residing in CMA, speaking official languages as the first language and having foreign work experience do not have a statistically significant effect on earnings.

When human capital and social capital are considered simultaneously with variations related to duration and location of work, the data of Table 2 (model 3) indicate that all the earnings differences among female immigrants of various racial backgrounds and origins remain statistically insignificant. The net effects of the number of weeks worked and working full time, and years in Canada remain virtually unchanged. Each year of schooling now increases the annual earnings by $\$ 1,991$. Foreign credentials held by female majority members bring an earnings premium of $\$ 3,770$ a year, but those held by female visible minority immigrants suffer a net loss of $\$ 413$ a year. However, the latter is not statistically significant.

The effects of ethnic social capital on earnings tend to be different for immigrant women compared to men. Having all or most friends of the same ethnic ancestry brings a net penalty in earnings of $\$ 3,110$ a year for immigrant women. Unlike immigrant men, the negative effects of ethnic coworkers are not significant among women, while immigrant women who belong to a social organization with few members of the same ethnic ancestry have an earnings advantage of $\$ 4,424$ a year compared to those not belonging to any social organization. The overall findings of social capital among immigrant women probably suggest a small assimilation effect: those who have almost all friends belonging to the same ethnic ancestry suffer a net earnings penalty and those who belong to a social organization with few members of the same ethnic ancestry receive an earnings premium.

When interaction terms are added to the model (Table 2, model 4), none of them produce a statistically significant effect. The effects of other 
variables remain virtually unchanged. As with the findings for men, there is no evidence that ethnic social capital mitigating the negative effects of foreign credential deficits.

The foregoing analysis indicates that there are gross earnings differences among immigrant men and women of various origins. When variations in human capital and social capital are controlled, much of the original difference is statistically insignificant. The only exception is for immigrant Black men, who continue to earn the least even after variations in other factors have been controlled. For immigrant men and women, human capital variables such as years of schooling and years in Canada bring an incremental effect on earnings, but foreign work experience produces no significant difference. Foreign credentials held by majority members, whether men or women, bring a net earnings advantage, but those held by visible minorities suffer an earnings penalty. Ethnic social capital measured by ethnic ties with friends, coworkers, and social organizations has different effects for immigrant men and women. In general, the negative effect of having too many coworkers of the same ancestry is apparent among immigrant men but not among immigrant women. For immigrant women, the negative effect of having too many friends of the same ancestry and the positive effect of belonging to a social organization with few members of the same ancestry are apparent. Thus, for both men and women, immigrants who have weak connections with ethnic members seem to have higher earnings.

These statistical relationships should be interpreted as correlational rather than causal. Based on the findings, it would be incorrect to assume that ethnic social capital is a cause of low income since some immigrants may seek out ethnic ties as possible sources of assistance given the prospect of low earnings. The findings do confirm that mobilizing ethnic social capital does not mitigate the effect of what the market deemed as a credential deficit.

\section{Conclusions}

The literature identifies two factors that are used to explain why some immigrants earn less than other immigrants in the Canadian labour market. The first factor is the lack of recognition for foreign credentials of immigrants in Canada, and the second one relates to a shifting origin of recent immigrants to non-European sources that implies a further discounting of foreign credentials held by immigrants of non-European origins. Immigrants with foreign credentials that result in an earnings disadvantage may be said to possess a credential deficit. The literature on 
social capital suggests that immigrants with a credential deficit may take advantage of ethnic social capital to compensate for the disadvantage. This paper uses data from the Ethnic Diversity Survey to see how foreign credentials affect the earnings of immigrant men and women, and to see if ethnic social capital measured by ties with ethnic friends, ethnic coworkers, and ethnic social organizations may have a mitigating effect for immigrants with a credential deficit.

The findings indicate that there are substantial variations in gross earnings among immigrant men and women of different origins. In general, visible minority immigrant men and women earn less than their majority counterparts respectively. However, when variations in human capital and duration of work are controlled, much of the gross earnings difference is not statistically significant, except for Black male immigrants who continue to have the lowest earnings. Thus, much of the gross difference in immigrants' earnings is due to variations in human capital and duration of work. Human capital variations in terms of years of schooling and years in Canada produce a positive effect on earnings for immigrant men and women, but foreign work experience for both gender groups is not recognized in the Canadian labour market. Foreign credentials do not necessarily bring a negative effect on immigrants' earnings. Foreign credentials held by immigrant men and women of majority member background enjoy an earnings premium compared to their counterparts who have Canadian credentials. Only immigrant men and women of visible minority background suffer an earnings penalty. Thus, visible minority immigrants with foreign credentials may be said to possess a credential deficit.

The findings on ethnic social capital indicate that immigrant men who work in an immigrant setting in which most of the coworkers are of similar ethnic background do not earn as much as other immigrant men who work in a nonenclave setting. This finding confirms what has been recently reported in the Canadian literature regarding the disadvantage in earnings for immigrants working in an immigrant enclave ( $\mathrm{Li}$ and Dong 2007). Immigrant men who have most friends of similar ethnic ancestry suffer a loss in earnings compared to other immigrant men with few such friends. Immigrant men who belong to a social organization in which most members have a similar ethnic origin have an earnings advantage over those who belong to no social organization. However, this advantage is substantially discounted for visible minority immigrant men with foreign credentials.

The negative effect associated with working in an enclave is not found among immigrant women. Similar to immigrant men, having too many ethnic friends brings a disadvantage in earnings. However, belong- 
ing to a social organization with few members of similar ethnic ancestry brings an advantage compared to those who do not belong to any social organization.

In general, the effects of various forms of ethnic social capital on the earnings of immigrant men and women are rather weak and uneven. Overall, they suggest an assimilation effect operating among immigrant men and women in that immigrants maintaining weaker ties with their ethnic communities tend to do better economically than those who maintain strong ties. Further, there is no evidence in this study to suggest that the negative effect of foreign credentials held by visible minorities can be mitigated by ethnic social capital.

The present study clarifies certain issues related to immigrant credentials and social capital. First, the tendency in the literature to view all foreign credentials of immigrant as being discounted in Canada is not correct. Credentials held by majority immigrant men and women earn a premium; the credentials held by visible minority immigrants produce a deficit. Second, the literature tends to stress the enabling capacity of social capital as measured by social ties. In the case of ethnic social capital, it is not clear if it enables immigrant to mitigate disadvantage conditions. When considered with the effect of human capital, immigrants with stronger ethnic ties tend to earn less than others with weaker ethnic ties. Those in possession of a credential deficit are unable to use ethnic social capital to mitigate or shelter the negative effect.

This study further suggests that foreign credentials of immigrants are racialized, since the market value of foreign credentials varies depending on the racial background of the immigrants. Despite the emphasis on the positive economic effects of social capital in the literature, this study fails to find evidence to indicate that it can be used as a substitute for human capital in the process of immigrants adjusting to the Canadian labour market.

\section{REFERENCES}

Abbott, Michael G. and Charles M. Beach. 1993. Immigrant earnings differentials and birth-year effects for men in Canada: Post-war-1972. Canadian Journal of Economics 26(3):505-524.

Aydemir, Abdudrrahman and Mikal Skuterud. 2005. Explaining the deteriorating entry earnings of Canada's immigrant cohorts, 1966-2000. Canadian Journal of Economics 38(2):641-672.

Bloom, David E., Gills Grenier, and Morley Gunderson. 1995. The changing labour market position of Canadian immigrants. Canadian Journal of Economics 28(4b):987-1005. 
Bloom, David E. and Morley Gunderson. 1991. An analysis of earnings of Canadian immigrants. Pp. 321-367 in J.M. Abowd and R.B. Freeman, eds., Immigration, Trade and the Labour Market. Chicago: University of Chicago Press.

Bonacich, Edna and John Modell. 1980. Economic Basis of Ethnic Solidarity. Berkeley and Los Angeles: University of California Press.

Bourdieu, Pierre. 1986. The forms of capital. Pp. 241-258 in J.G. Richardson, ed., Handbook of Theory and Research for the Sociology of Education. Westport, CT: Greenwood Press.

Coleman, James S. 1988. Social capital in the creation of human capital. American Journal of Sociology 94 (Supplement):S95-S120.

Coulson, R.G. and D.J. DeVoretz. 1993. Human capital content of Canadian immigrants, 1967-1987. Canadian Public Policy 19(3):357-366.

Cummings, Scott, ed. 1980. Self-Help in Urban America: Patterns of Minority Business Enterprise. Port Washington, NY: Kennikat Press.

deSilva, Arnold. 1997. Earnings of immigrant classes in the early 1980s in Canada: A reexamination. Canadian Public Policy 23(2):179-202.

Frenette, Marc and Rene Morissette. 2003. Will They ever Converge? Earnings of Immigrants and Canadian-born Workers over the last two Decades. Business and Labour Market Analysis, Statistics Canada, Catalogue No. 11F0019MIE, No. 215.

Granovetter, Mark. 1985. Economic action and social structure: The problem of embeddedness. American Journal of Sociology 91(3):481-510.

1995. The economic sociology of firms and entrepreneurs. Pp. 128-165 in A. Portes, ed., The Economic Sociology of Immigration. New York: Russell Sage.

Green, David A. and Christopher Worswick. 2002. Earnings of immigrant men in Canada: The roles of labour market entry effects and returns to foreign experience. Paper prepared for Strategic Research and Statistics, Citizenship and Immigration Canada.

Kalbach, Madeline A. and Warren E. Kalbach. 1995. The importance of ethnicconnectedness for Canada's post-war immigrants. Canadian Ethnic Studies 27(2):16-33.

Li, Peter S. 2001a. The market worth of immigrants' educational credentials. Canadian Public Policy 27(1):1-16.

2001b. The economics of minority language identity. Canadian Ethnic Studies 33(3):134-154.

2004. Social capital and economic outcomes for immigrants and ethnic minorities. Journal of International Migration and Integration 5(2):171190. 
Li, Peter S. and Chunhong Dong. 2007. Earnings of Chinese immigrants in the enclave and mainstream economy. Canadian Review of Sociology and Anthropology 44(1):65-99.

Light, Ivan. 1972. Ethnic Enterprise in America. Berkeley and Los Angeles: University of California Press.

Light, Ivan and Edna Bonacich. 1988. Immigrant Entrepreneurs. Berkeley and Los Angeles: University of California Press.

Light, Ivan and Steven J. Gold. 2000. Ethnic Economies. San Diego: Academic Press.

Light, Ivan and Carolyn Rosenstein. 1995. Race, Ethnicity, and Entrepreneurship in Urban America. New York: Aldine de Gruyter.

Lin, Nan, Karen Cook, and Ronald S. Burt, eds. 2001. Social Capital. New York: Aldine De Gruyter.

Pendakur, Krishna and Ravi Pendakur. 2002. Language as both human capital and ethnicity. International Migration Review 36(1):147-177.

Portes, Alejandro and Julia Sensenbrenner. 1993. Embeddedness and immigration: Notes on the social determinants of economic action. American Journal of Sociology 98(6):1320-1350.

Portes, Alejandro and Min Zhou. 1996. Self-employment and the earnings of immigrants. American Sociological Review 61(2):219-230.

Putnam, Robert D. 1993. Making Democracy Work: Civic Traditions in Modern Italy. Princeton, NJ: Princeton University Press

Reitz, Jeffery G. 1998. Warmth of the Welcome. Boulder, CO: Westview Press. 2001a. Immigrant skill utilization in the Canadian labour market: Implications of human capital research. Journal of International Migration and Integration 2(3):347-378.

2001b. Immigrant success in the knowledge economy: Institutional change and the immigrant experience in Canada, 1970-1995. Journal of Social Issues 57(3):579-613.

Reitz, Jeffrey G. and Raymond Breton. 1994. The Illusion of Difference: Realities of Ethnicity in Canada and the United States. Toronto: C.D. Howe Institute.

Reitz, Jeffrey G. and Sherrilyn M. Sklar. 1997. Culture, race, and the economic assimilation of immigrants. Sociological Forum 12(2):233-277.

Schaafsma, Joseph and Arthur Sweetman. 2001. Immigrant earnings: Age at immigration matters. Canadian Journal of Economics 34(4):1066-1099.

Statistics Canada. 2002. Ethnic Diversity Survey: User Guide.

Waldinger Roger, Howard Aldrich, Robin Ward, and Associates. 1990. Ethnic Entrepreneurs: Immigrant Business in Industrial Societies. Newbury Park, CA: Sage. 
Wanner, Richard A. 2003. Entry class and the earnings attainment of immigrants to Canada, 1980-1995. Canadian Public Policy 29(1):53-71.

Ward, Robin and Richard Jenkins, eds. 1984. Ethnic Communities in Business. Cambridge: Cambridge University Press.

Wiley, Norbert. 1967. The ethnic mobility trap and stratification theory. Social Problems 15(2):147-159.

Wilson, Kenneth L. and W. Allen Martin. 1982. Ethnic enclave: A comparison of the Cuban and Black economies in Miami. American Journal of Sociology 88(1):135-160.

Wilson, Kenneth L. and Alejandro Portes. 1980. Immigrant enclaves: An analysis of the labour market experiences of Cubans in Miami. American Journal of Sociology 86(2):295-319.

Worswick, Christopher. 2004. Immigrants' declining earnings: Reasons and remedies. C.D. Howe Institute Backgrounder 81:1-9.

Peter S. Li is professor of sociology at the University of Saskatchewan. He is author of many papers and books, including Destination Canada, The Chinese in Canada, and The Making of Post-War Canada. He is also the editor of The Journal of International Migration and Integration. 